Western University

Scholarship@Western

FIMS Publications

Information \& Media Studies (FIMS) Faculty

2015

Indigenous and Black Intellectuals in the Lettered City

Jason Dyck

jdyck3@uwo.ca

Follow this and additional works at: https://ir.lib.uwo.ca/fimspub

Part of the Latin American History Commons

Citation of this paper:

Dyck, Jason, "Indigenous and Black Intellectuals in the Lettered City" (2015). FIMS Publications. 248.

https://ir.lib.uwo.ca/fimspub/248 


\title{
INDIGENOUS AND BLACK INTELLECTUALS IN THE LETTERED CITY
}

\author{
Jason Dyck \\ Trent University Durham
}

Saints and Citizens: Indigenous Histories of Colonial Missions and Mexican California. By Lisbeth Haas. Berkeley: University of California Press, 2013. Pp. xii + 256. $\$ 65.00$ cloth. $\$ 34.95$ paper. ISBN: 9780520280625.

The Black Doctors of Colonial Lima: Science, Race, and Writing in Colonial and Early Republican Peru. By José R. Jouve Martín. Montreal, Canada: McGill-Queen's University Press, 2014. Pp. xii + 209. \$39.95 cloth. ISBN: 9780773543416.

The Learned Ones: Nahua Intellectuals in Postconquest Mexico. By Kelly S. McDonough. Tucson: University of Arizona Press, 2014. Pp. xiii +280 . $\$ 55.00$ cloth. ISBN: 9780816511365.

Missionary Scientists: Jesuit Science in Spanish South America, 1570-1810. By Andrés I. Prieto. Nashville, TN: Vanderbilt University Press, 2011. Pp. x 287. \$59.95 cloth. ISBN: 9780826517449.

Indigenous Intellectuals: Knowledge, Power, and Colonial Culture in Mexico and the Andes. Edited by Gabriela Ramos and Yanna Yannakakis. Durham, NC: Duke University Press, 2014. Pp. xviii + 323. \$89.95 Cloth. \$24.95 paper. ISBN: 9780822356608.

In the past, Spaniards, creoles, Indians, and blacks were all kept in neatly separate explanatory categories to analyze conquest, conversion, and cultural change from initial contact to the wars for independence. Spaniards, so the old colonial story was told, were the brave and self-sacrificing spiritual and military conquerors of Amerindian empires and African slaves. They were also the most talented artists in the principal viceregal cities and the only ones who wrote about historical themes and other scientific matters. Several new currents of research have significantly complicated these oversimplified dichotomies of colonial life. The more nuanced picture emerging is that of Indian and black conquistadors and missionaries who, alongside Europeans, subjugated indigenous polities and converted the masses, developing local Christianities in light of their own cultural assumptions. And now, instead of being mere slavish imitators of European art and illiterate neophytes in rural doctrinas (proto-parishes), Indians and blacks are increasingly seen as artists and authors whose works deserve to be treated together with those of Spaniards and creoles.

The five books under review in these pages contribute to these larger trends in scholarship by opening up the elite and exclusively urban doors of The Lettered 
City. ${ }^{1}$ In this classic work, Ángel Rama envisions the viceregal city as a visible and material symbol of colonial order, one in which another "lettered city" of religious men, administrators, educators, and authors controlled access to power through their mastery of the pen and access to books. His letrados (men of letters), however, are primarily of a lighter complexion, stemming from the noble ranks of Spaniards, creoles, and a few ascending mestizos. But as this cluster of new studies convincingly demonstrates, Indians and blacks-as informants to missionaries and anthropologists or as authors and artists-were also intellectuals who wrote histories and scientific treatises, made legal demands, and performed other unwritten forms of scholarly activity that contributed significantly to colonial societies and modern nations, both in the centers of viceregal power and on the frontier. As a group, these five books reinforce the idea that colonialism and modern nation building in Latin America were collaborative endeavors that included people from all socioracial backgrounds.

Collaboration is central to Andrés I. Prieto's Missionary Scientists, a detailed tour of Jesuit naturalists in South America during the late sixteenth and seventeenth centuries. In his work scientific exploration and evangelical activities go hand in glove because missions were sites of both intellectual pursuits and spiritual encounters. That scientific knowledge was acquired in the mission context is not a new discovery, especially considering the vast scholarship on José de Acosta and a recent translation of his commonly cited Natural and Moral History of the Indies. ${ }^{2}$ The originality of Prieto's work lies in his concentration on the midcolonial period, because he compares Acosta to other well-known yet understudied Jesuits, namely Bernabé de Cobo, Nicolo Mascardi, Alonso de Ovalle, and Diego de Rosales. These men, according to Prieto, developed the larger intellectual "tradition of observation, reflection, and writing about America" (223) that exiled Jesuits in Italy-most famously Francisco Javier Clavijero and Juan de Velasco-drew upon to defend their patrias from theories of American degeneracy espoused by the likes of Cornelius de Pauw, Georges-Louis Leclerc (comte de Buffon), and William Robertson. Antonello Gerbi's Dispute of the New World, as a result, needs to be pushed back by at least a century and must consider the complexities and patriotic elements of baroque science. ${ }^{3}$

Why were Jesuit missionaries in the midcolonial period so concerned about the natural world? Prieto explains that unlike their European brethren, Jesuits in the viceroyalty of Peru were unable to devote their full energies to intellectual pursuits because they were scarce in numbers and needed in the mission field. By the 1570s the Society of Jesus expanded beyond its urban colleges to administer Indian doctrinas and reducciones (reductions), a crucial transition for the development of colonial science because the black robes encountered "opportunities and challenges" (35) that forced them to combine their interests in nature with the

1. Ángel Rama, La ciudad letrada (Hanover: Ediciones del Norte, 1984).

2. José de Acosta, Natural and Moral History of the Indies, trans. Frances López-Morillas, ed. Jane E. Mangan (Durham, NC: Duke University Press, 2002).

3. Antonello Gerbi, The Dispute of the New World: The History of a Polemic, 1750-1900, trans. Jeremy Moyle (1955; Pittsburgh: University of Pittsburgh Press, 1973). 


\section{Latin American Research Review}

salvation of souls. Native healers used local herbs and plants for both medicinal and ritual purposes, which is why the Jesuits sought to control access to medical care on their reductions. By becoming medicine men they were able to combat the power of local shamans, a missionary strategy that implied direct observation of the natural world and the collection of data. But despite their passion for measuring the stars and gathering ethnobotanical information, Prieto's Jesuits still pray, confess, administer the sacraments, and preach and teach Christian doctrine. Missionary Scientists offers an interesting contrast to many studies that primarily represent missionaries as early ethnographers.

While stationed on remote missions, Jesuits still managed to form part of a larger community of naturalists across Spanish America and Europe. Prieto suggests that the structure of the Society of Jesus fostered "a truly collaborative way of understanding the study of nature" (92). The established network of colleges enabled missionaries to exchange scientific information and instruments with other members and to return to impressive libraries in urban centers. Jesuits were also extremely mobile, obediently changing colleges, missions, and residencies several times throughout their careers. Bernabé de Cobo, one of the four naturalists at the heart of Prieto's study, ministered in many cities in both Peru and New Spain, which provided him with the opportunity to visit surrounding areas, use local archives, collect data, and converse with fellow travelers. Epistolary exchanges also contributed to the diffusion of scientific information, as Jesuits in the Americas were able to both correct and communicate their findings with coreligionists in Europe. As a missionary among the Mapuche and Poya, Nicolo Mascardi, another naturalist whose work Prieto highlights, supplied information on the nature of Spanish South America and conducted astronomical experiments for the German polymath Athanasius Kircher. Several aspects of Prieto's imaginative reconstruction of Jesuit networks are certainly applicable to other forms of scholarly activity in the Indies, specifically sacred historians who traveled widely and employed similar research techniques to acquire information on local religious traditions.

Jesuit naturalists in Missionary Scientists rarely converse with other religious men, but they do frequently collaborate with indigenous peoples. Drawing upon Mary Louise Pratt's concept of the "contact zone," Prieto views Jesuit missions as "imperial spaces" where Indians and Europeans exchanged information within asymmetrical relations of power. ${ }^{4}$ In their eagerness to adapt to local conditions, Jesuits were transformed into students of indigenous peoples, a form of "intellectual interaction" that became "one of the staples of Jesuit scientific activity in South America" (33). On their missions in Chile, Jesuits used confession "to turn native penitents into informants" (58) to extract information about the medicinal value of plants; in Jesuit chronicles from the reductions of Paraguay "the agency of native informants and nurses" (81) is occluded because they viewed Guaraní botanical lore as demonic; from Peru to New Spain Cobo "used native informants extensively" (110) to acquire astronomical knowledge; and most of Rosales's eth- 
nobotanical data "came directly from native informers" (213). Although Prieto is sensitive to the role of indigenous people in Jesuit natural histories, the knowledge produced therein is primarily European and creole. The indigenous people in Missionary Scientists are sources of information and, generally speaking, not intellectuals in their own right.

Transforming indigenous informants into full-fledged intellectuals is Kelly McDonough's task in The Learned Ones, an ambitious study of Nahua scholars and writers from the sixteenth through the twentieth centuries. Nahuatl is among the best-recorded indigenous languages in the Americas, with up to 1.5 million native speakers today. Despite the wealth of documentation in Nahuatl from the colonial period, there was a significant decline after 1763, when Spanish became the sole administrative language of the empire. After independence, Spanish was declared the official language of Mexico, and liberals initiated patterns of suppression and discrimination that have persisted to the present day. Despite this deep-seated opposition to Nahuatl, McDonough argues that well before a renaissance in the mid-1980s, Nahua-speaking peoples had always maintained "deep engagement with the written word as one of the vehicles for their intellectual work" (3). She challenges the idea that indigenous peoples should be characterized solely by their production of oral histories, interpretive dances, and painted modes of expression. Ever since Nahuas learned the alphabetic script, they have used European forms of writing as tools to negotiate and contest colonialism and to jockey for their place in modern Mexico.

McDonough's approach to Nahua intellectuals is unique because The Learned Ones is a scholarly endeavor, personal journey, and service project all combined into one volume. She moves seamlessly between the past and the present, guiding the reader through the letters of her Anishinaabe great-grandmother, interviews with contemporary Nahua writers, and Reading Circles with native speakers of Nahuatl today. Instead of simply studying and writing about Nahua intellectuals, McDonough reads together with them to explore "collaborative methods" that will support the "recovery and revitalization of Nahuatl language and culture" (27). This collaborative approach is also present in the short "think-pieces" between chapters entitled tlen naman, which provide brief biographies and writings by contemporary native speakers in both Nahuatl and English translation. Although McDonough acknowledges and builds upon the work of New Philology pioneered by James Lockhart, ${ }^{5}$ she rejects the idea that only one who "writes or works in his/her native language" (14) should be considered a "true" indigenous intellectual. Given the official efforts to uproot their language, Nahua-speaking peoples were often forced to turn to Spanish to assert their rights and to engage with both the Spanish crown and the Mexican state.

To explore Nahua intellectuals in the colonial period, McDonough turns to the work of Antonio del Rincón and Juan Buenaventura Zapata y Mendoza. Rincón was a Jesuit priest and the first native speaker to produce a grammar of Nahuatl. Zapata, on the other hand, was a noble Tlaxcalan who composed a set of annals

5. James Lockhart, The Nahuas after the Conquest: A Social and Cultural History of the Indians of Central Mexico, Sixteenth through Eighteenth Centuries (Stanford, CA: Stanford University Press, 1992). 
for his altepetl (ethnic state). While there is recent work on Zapata in English ${ }^{6}$ there is little on Rincón, making McDonough's analysis of the Jesuit an important contribution to our knowledge of the early missionary theater. After early attempts to build an Indian priesthood failed, church authorities in New Spain barred indigenous peoples and mestizos from ordination between 1555 and 1585. That Rincón joined the Society of Jesus during this time demonstrates how certain decrees were ignored to respond to pressing concerns, and in the case of the Jesuits it was their need for native speakers. McDonough compares Rincón to Andrés de Olmos and Alonso de Molina-the first two Franciscans to write grammars of Nahuatl-to demonstrate how certain phonological aspects of Nahuatl, namely contrastive vowel length and pronunciation, were lost on European friars and Jesuits. These linguistic details were crucial for evangelization, especially considering that the mispronunciation of a word could change its meaning from washing one's hands to cutting them off!

After independence Indians ceased to exist legally and were transformed from subjects to citizens. But this does not mean that they all became mestizos and left their language and culture behind. Faustino Galicia Chimalpopoca was a professor of law and Nahuatl who defended indigenous communities in nineteenth-century Mexico. Although his unpopular decision to side with Maximilian I during the French Intervention (1862-1867) has obscured his legacy, McDonough argues that his life demonstrates how Nahua intellectuals "participated in modernity" (115). The same holds true for the twentieth century. Julia Jiménez González (doña Luz) collaborated with anthropologists by telling them Nahua tales and posing for artists such as Diego Rivera. Her life story fits within the larger testimonio genre with the likes of Rigoberta Menchú Tum and Rosa Isolde Reuque Paillalef.7 Drawing upon recent currents in anthropology, McDonough rightly criticizes how these types of women have often been considered "source[s] of knowledge, but not . . knowledge producer[s]" (134). The Learned Ones closes with the life of Ildefonso Maya Hernández, whose play Ixtlamatinij (The Learned Ones) criticizes assimilation projects of bilingual education by the Mexican state in the 1970s and 1980s.

Although "socially, politically, and economically marginalized" (202) across five centuries, McDonough concludes that Nahua intellectuals have always "availed themselves of the technology and practice of writing" (199). But the five individuals she examines to demonstrate this trend are primarily confined to the central valley of Mexico and set apart from other scholarly currents in Spanish America. Indigenous Intellectuals provides this larger interpretive framework, especially for those of the colonial period like Rincón and Zapata. Edited by Gabriela Ramos and Yanna Yannakakis, this volume of ten essays with a conclusion by Tristan Platt concentrates on Indian intellectualism in both New Spain and Peru

6. Susan Schroeder, ed., The Conquest All Over Again: Nahuas and Zapotecs Thinking, Writing, and Painting Spanish Colonialism (Eastbourne: Sussex Academic Press, 2010).

7. Rigoberta Menchú Tum, I, Rigoberta Menchú: An Indian Woman in Guatemala, ed. Elisabeth BurgosDebray, trans. Ann Wright (1983; London: Verso, 2009) and Rosa Isolde Reuque Paillalef, When a Flower in Reborn: The Life and Times of a Mapuche Feminist, ed. and trans. Florencia E. Mallon (Durham, NC: Duke University Press, 2002). 
from primarily the sixteenth and early seventeenth centuries. Instead of focusing only on an established canon of indigenous writers like Domingo Francisco de San Antón Muñón Chimalpahin and Felipe Guaman Poma de Ayala, Indigenous Intellectuals also considers the lives, writings, and work of local interpreters, scribes, fiscales (native assistants), sacristans, notaries, and legal agents. By analyzing "practical action" and what indigenous people did "to make colonial society viable," this volume moves "beyond the assumption that intellectuals were those who wrote" (1).

Among the most important contributions of Indigenous Intellectuals to colonial studies is its comparative framework, for Mexicanists and Andeanists often work in isolation from each other. By studying literacy, litigation, and letrados in both New Spain and the Andes, the spread of alphabetic writing in both regions is placed in a new light. It is well known that Indians in New Spain had pictographic texts to record their histories while Andeans used quipus (cords with knotted strings) as their primary form of record keeping. But how do we explain that far more indigenous languages were alphabetized in New Spain than in Peru? Why did a notarial culture in native tongues flourish in the former but not in the latter? Ramos argues that since the Mexica empire was far more decentralized and urbanized than its Incan counterpart, a greater volume of independent intellectuals developed there within local bureaucracies. These pre-conquest differences were only heightened during the colonial period, especially considering that a greater number of indigenous writers emerged in New Spain than in Peru. Furthermore, Platt explains that in comparison to New Spain, indigenous litigation was significantly supressed in the Andes, colonial officials mistrusted quipus as records for auditing local communities, and tributary requirements and labor regimes were much harsher. In this context, Spaniards in Peru preferred legal documentation in Spanish to better control the indigenous population, while Andeans turned to Spanish to defend their communities more effectively.

Even though writing was not as widespread in the Andes as it was in New Spain, both regions were sites of native scholarly activity. Indigenous Intellectuals provides an important parallel to Spanish and creole research methods, some of which were outlined by Prieto. Susan Schroeder, for example, describes how Chimalpahin most likely worked in the library of the San Francisco church in Mexico City, a collection of sources in Latin, Nahuatl, and Spanish. He also carried out interviews with elders and relatives and collected and compared annals, the same methods sacred historians used to write about their religious brethren, provinces, and images. Kathryn Burns notes that in the Andes fiscales were often given charge over parish archives and hence were responsible for organizing records of births, deaths, marriages, and confessions. There were also escribanos del cabildo (municipal scribes), who in most cases had archives under their care containing translated quipus, acts of the cabildo (town council), wills, and accounts from community chests. These examples offer important counterpoints to the standard image of colonial archives: a creole savant seated at his desk surrounded by manuscripts and books. Moreover, beyond their role as archivists, Indians were also "ethnographers." Alan Durston argues that Cristóbal Choquecasa was the author of the anonymous Huarochiri Manuscript, a text in Quechua 


\section{Latin American Research Review}

describing local Andean religion. He suggests that Choquecasa worked with informants to acquire information about the pre-Hispanic past and performed his own "fieldwork" (155), methods that are often only associated with mendicant friars and Jesuits.

Indigenous Intellectuals also provides new ways of understanding the educational process whereby Indians acquired their research and archival skills. A significant amount has been written about schools for Indian nobles, most famously the Colegio de la Santa Cruz de Santiago de Tlatelolco. John Charles indicates, however, that these studies have often interpreted "education as conquest" and hence assumed that "native students were obedient cultural ambassadors, strictly aligned with the goals of Spanish colonialism" (61). By following graduates from Jesuit schools for indigenous elites in Lima and Cuzco, Charles demonstrates that natives used their education to further their own interests in local courts. But as important as colleges and universities were for training indigenous people in European ways, Ramos suggests that "a good part of education, knowledge, and learning took place elsewhere" (31). One needs to consider the homes of mestizo teachers, houses of devotion, and convents where Indian servants obtained informal schooling outside of official channels. It should also be kept in mind that Spaniards, creoles, and mestizos were not the only teachers of literacy in colonial societies. Yannakakis points out that given the absence of parish priests, at times native functionaries taught reading and writing along with Christian doctrine as lay catechists.

Given its primary focus on central Mexico and the Andes, Indigenous Intellectuals ignores other native scholars working on the frontiers of Spanish America. Lisbeth Haas's study of Catholic missions in California fills this gap. Saints and Citizens follows indigenous responses to Spanish colonial rule and Mexican independence in Chumash, Luiseño, and Yokuts territories from 1769 to 1848. Although missions symbolized dislocation and death for indigenous peoples, Hass persuasively argues that they were still "sites of Indigenous authority, memory, identity, and historical narration" where native leaders drew upon their own past to "seek redress and to sustain the community" (7). Following in the footsteps of "new mission history," she takes the spotlight away from the traditionally heroic Franciscan friar and hands it over to indigenous translators, artisans, and scholars who skillfully moved between distinct cultural worlds.

On California missions natives were reclassified as legal minors, given new names after the saints, subjected to the possibility of corporal punishment, and only permitted to leave with a pass. Despite these "humiliating conditions," Haas builds upon decades of scholarship on Indian survival" to highlight the ways in which natives used their own knowledge and power "to help people survive in the wake of shattered worlds" (82). Natives may have been forced to wear new clothes, but they still distinguished themselves through their tattoos, beads, amu-

8. Erick Langer and Robert H. Jackson, eds., The New Latin American Mission History (Lincoln: University of Nebraska Press, 1995).

9. For a pioneering example, see Nancy M. Farriss, Maya Society under Colonial Rule: The Collective Enterprise of Survival (Princeton, NJ: Princeton University Press, 1984). 
lets, and the talismans they hung around their necks. In certain parts of Luiseño territory healers persisted, astrologers continued to practice their craft, and ritual practices around death remained. Similar to other indigenous groups across the Americas, those in California accepted Christianity but maintained former ways to the sacred by developing a "translated Christianity."10 Haas explains that after baptism the Chumash were assigned godparents, many of whom became the principal educators of Catholic doctrine and spiritual care on the missions. She also notes that among the Luiseños a blind interpreter taught other translators how to render Christian prayers and teachings in their own language. But it was dance that "formed a critical part of mission life" (73), allowing indigenous people in California to maintain pre-Hispanic rituals for both healing and the harvest. More importantly, it was a medium through which elders actively sustained traditional forms of knowledge within the constraints of the mission system.

Pre-Hispanic forms also survived on the missions through the visual record. Similar to Catholic missionaries in other contexts around the globe, Franciscan friars needed indigenous artisans and craftsmen to build churches and paint and carve Christian images. In the past few decades a wealth of studies on the politics of images and indigenous art have dismantled earlier suggestions that most preconquest visual forms became extinct in the wake of colonization. ${ }^{11}$ Haas views mission art in California through this interpretive lens, highlighting how Indian painters incorporated their own iconography, visual systems, and meanings into the biblical story. She points out that native painters often worked without master craftsmen and that in certain cases indigenous artisans performed their tasks with virtually no missionary supervision. It was in this environment that native sensibility and aesthetics influenced the internal decor of mission churches. Haas provides examples of zigzags framing Catholic images following traditional rock painting, a sculpture of Christ in a dance skirt capturing native beliefs and practices, and a painting of the Archangel Raphael representing a local Chumash leader. These examples of "resistance and native power" (90) and "multivalent meanings" (96) in indigenous art find parallels in central Mexico and the Andes, welcomed connections Haas makes to place the California missions in the larger context of Spanish America.

Haas does not directly engage with New Conquest History, but her turn to "indigenous archives" fits into larger scholarly trends seeking after indigenous sources, categories, and interpretations of conquest and colonial rule. ${ }^{12}$ In her search for a "multivocal explanation" (184) of mission history, Haas skilfully

10. Still relevant to this topic is Inga Clendinnen, “Ways to the Sacred: Reconstructing 'Religion' in Sixteenth Century Mexico," History and Anthropology 5, no. 1 (1990): 105-141.

11. For two earlier examples, see Gauvin Alexander Bailey, Art on the Jesuit Missions in Asia and Latin America, 1542-1773 (Toronto: University of Toronto Press, 1999), and Serge Gruzinski, Images at War: Mexico from Columbus to Blade Runner (1492-2019), trans. Heather MacLean (1990: Durham, NC: Duke University Press, 2001).

12. For two examples, see Laura E. Matthew and Michel R. Oudijk, eds., Indian Conquistadors: Indigenous Allies in the Conquest of Mesoamerica (Norman: Oklahoma Press, 2007), and Laura E. Matthew, Memories of Conquest: Becoming Mexicano in Colonial Guatemala (Chapel Hill: University of North Carolina Press, 2012). 


\section{Latin American Research Review}

places ethnographic reports by Franciscan missionaries into conversation with indigenous historians like Pablo Tac. But even though a handful of Indians learned how to read and write, missions were primarily places where oral culture prevailed. Similar to McDonough's approach to doña Luz, Haas treats the Chumash informants of the ethnologist John P. Harrington as historians in their own right. She draws upon the stories of Maria Solares, Lucretia Garcia, and Luisa Ignacio to reconstruct an indigenous view of the Chumash War in 1824, an interethnic and intertribal revolt against the missions and government of California. Their versions of the past differ in narrative structure, focus on indigenous leaders, and are rooted in Indian forms of power. The political vision that emerges in these oral histories mirrors the actions of other indigenous citizens of Mexico who wrote their own requests for emancipation from the missions, fought for their rights, defined the shape of their freedom, and elected representatives to protest on their behalf. "Indigenous people," Haas concludes, "were too rarely considered political subjects in California history" (182).

Thus far the books under review have concentrated on the intellectual activity of indigenous peoples in urban centers and frontier missions. Clearly Indians deserve recognition as letrados in colonial times and as scholars in the post-independence period. But to their ranks should also be added people of African descent. Recent scholarship on Afro-Latin America provides an important reminder that major colonial cities in New Spain and Peru contained large numbers of blacks, mulattos, and pardos (browns). Not only this, but modern countries like Argentina and Uruguay - traditionally seen as "whiter" nations in the region-were deeply influenced by African traditions, most specifically dance. ${ }^{13}$ In The Black Doctors of Colonial Lima José R. Jouve Martín adds to this growing literature on Afro-Latin America by highlighting the "black and mulatto surgeons whose names and activities have mostly been lost to history" (135). Concentrating on the transition from colony to republic in Peru between 1760 and 1840, Jouve follows the careers and scientific writings of three limeño mulattos: José Manuel Valdés, José Manuel Dávalos, and José Pastor de Larrinaga. He places this trio of medical practitioners into the community of Spanish and creole letrados, arguing that their lives challenge "many existing assumptions about the relationship between race and knowledge in the cities of colonial and early republican South America" (xvi).

The Black Doctors of Colonial Lima inserts Afro-Peruvians into larger debates about the Black Legend that guided earlier studies of intellectual production in the Spanish world. Scholars are increasingly aware that the viceroyalties of $\mathrm{New}$ Spain and Peru were not entirely sheltered from the latest ideas of the Enlightenment. Iberia and its overseas possessions also contributed to scientific production in the early modern period and thus need to be considered alongside other European powers in the Atlantic world. Jouve demonstrates how mulatto doctors par-

13. See John Charles Chasteen, National Rhythms, African Roots: The Deep History of Latin American Popular Dance (Albuquerque: University of New Mexico Press, 2004); George Reid Andrews, Blackness in the White Nation: A History of Afro-Uruguay (Chapel Hill: University of North Carolina Press, 2010); and George Reid Andrews, Afro-Latin America, 1800-2000 (Oxford: Oxford University Press, 2004). 
ticipated in the Spanish American Enlightenment by playing important roles in a scientific revolution in Peru in the second half of the eighteenth century, one that profoundly influenced the medical profession. Valdés and Larrinaga published articles in the Mercuriano Peruano, a leading journal dedicated to the promotion of science and social reform. Despite their racial origins, their work fits into a larger body of texts that Jorge Cañizares-Esguerra has described as creole patriotic science. ${ }^{14}$ Similar to the creole Jesuits referenced by Prieto, Larrinaga sought to disprove theories of American degeneracy espoused by de Pauw, while Dávalos elaborated upon the healthy climate of Lima. In their writings they "took ownership of the protonationalist sentiments of the criollo elite" (54). While studies of creole patriotism naturally focus on creoles and a few Spanish émigrés, Jouve demonstrates that mulattos also need to be included in the expanding literature on this theme. ${ }^{15}$

Also revealing in The Black Doctors of Colonial Lima is the role of Afro-Peruvians in early republican Peru. Many recent studies have stressed the importance of black and mulatto soldiers in the wars for independence and as allies in the conservative-liberal conflicts of the nineteenth century. ${ }^{16}$ But as Jouve points out in the Peruvian case, they also played a crucial role in the development of medical pluralism that is still characteristic of many regions of Latin America today. ${ }^{17}$ During the colonial period blacks and mulattos were surgeons and doctors in Lima, but they also practiced medicine in informal ways as curanderos (healers), hechiceros (sorcerers), and ensalmadores (healers who recited the psalms) by mixing popular Spanish and Andean medical practices with African forms of healing. Although several were persecuted, Martín de Porres, an early seventeenth-century mulatto and donado (religious servant) of the Dominican order, acquired a popular reputation as a folk healer and miracle-working saint. Eventually beatified in 1837, Martín's pious fame had endured in the same way that "traditional medical practitioners remained very popular after independence" (101). José Manuel Valdés witnessed this event and these continuities as the chief medical officer of the Republic of Peru. His vida (life) of Martín, according to Jouve, was a "symbolic closure to the participation of blacks and mulattoes in Peruvian medicine" (134).

Collectively these new books show that just as any given city in Latin America is a site of multiethnic activity, so too is the production of knowledge. In both the colonial and modern periods native informants, indigenous intellectuals, Nahua

14. Jorge Cañizares-Esguerra, Nature, Empire, and Nation: Explorations of the History of Science in the Iberian World (Stanford, CA: Stanford University Press, 2006).

15. See David A. Brading, The First America: The Spanish Monarchy, Creole Patriots, and the Liberal State, 1492-1867 (Cambridge: Cambridge University Press, 1991). For a more recent study, see Ralph Bauer and José Antonio Mazzotti, eds., Creole Subjects in the Colonial Americas: Empires, Texts, Identities (Chapel Hill: University of North Carolina Press, 2009).

16. For two recent examples, see Peter Blanchard, Under the Flags of Freedom: Slave Soldiers and the Wars of Independence in Spanish South America (Pittsburgh: University of Pittsburgh Press, 2008) and James E. Sanders, Contentious Republicans: Popular Politics, Race, and Class in Nineteenth-Century Colombia (Durham, NC: Duke University Press, 2004).

17. For medical pluralism, see David Sowell, The Tale of Healer Miguel Perdomo Neira: Medicine, Ideologies, and Power in the Nineteenth-Century Andes (Wilmington, DE: Scholarly Resources, 2001). 
and Chumash historians, and black doctors shared their wisdom with others, performed research in libraries and archives, wrote important works of history and science, and fought for their rights as citizens in newly emerging nations. The five studies reviewed here have significantly expanded the "lettered city" and in so doing have complicated traditional ways of understanding intellectuals and the general transmission of knowledge in colonial and modern Latin America. 